\title{
O DIÁLOGO DOS MORTOS DE PAUL VALÉRY
}

\author{
Brutus Abel Fratuce Pimentel
}

1.

A ideia de um "mundo dos mortos" esteve presente na filosofia de Platão, que a utilizou tanto para fins epistemológicos quanto éticos e estéticos. Em seu diálogo Fedro, ele imagina um lugar supra-celeste, que "nenhum poeta cantou nem jamais cantará dignamente" (PLATO, Phaedrus, 2005, p. 475) e onde a alma, de homens e deuses, é comparada a um carro alado composto por um cocheiro, representante da razão, e por dois cavalos: ambos dóceis, no caso da alma dos deuses; um dócil e o outro indócil, no caso da dos homens. Numa eterna cavalgada, a alma dos homens, ao contrário da dos deuses, é aquela que não conseguiria manter por muito tempo o equilíbrio. Daí a queda; daí as sucessivas reencarnações no "mundo dos vivos" e tudo o que advém ao se ter um corpo perecível, que nasce, cresce e envelhece. Em seu estado original ou natural, a alma dos homens também seria capaz de contemplar, de acordo com o seu maior ou menor grau de pureza, uma maior ou menor quantidade destes "entes eternos" não sujeitos ao devir do mundo sensível, material, as Ideias, formas, modelos ou arquétipos, regras ou leis, sobretudo de objetos matemáticos e de objetos de valores (como o belo, o bom, o justo etc.). Quando, entretanto, envolta por um corpo, a alma perceberia apenas as coisas sensíveis, materiais, com exceção 
daquela que se dedicasse à filosofia, capaz ao menos de ter certo vislumbre das Ideias. O que insinuaria certa relação, certo ponto de contato, certa participação, entre o "mundo dos mortos" e o "mundo dos vivos". (Cf. PLATO, Phaedrus, 2005) Supõe-se que, depois da morte, o homem, voltando a ser somente alma, voltando a ser aquilo que sempre foi, poderá novamente contemplar aquilo que em vida não era tão capaz. (Cf. PLATO, Phaedo, 2005)

Toda essa cosmovisão poderia facilmente sugerir a escrituração de um diálogo dos mortos. Na Modernidade, talvez tenha sido o poeta e pensador Paul Valéry o autor que mais diretamente explorou essa rica possibilidade formal, descrevendo a imaginária aventura intelectual e memorialista de um Sócrates e de um Fedro, ambos desencarnados, ante um estranho mundo não-sensível, não-material. No seu célebre dialogues des morts, o Eupalinos ou l'architecte ${ }^{1}$ (1921), ele não se questiona sobre o porquê do fenômeno da morte, pois a morte, "essa aventura extraordinária, essa modificação mágica, essa coisa incrível que/ acontece a todos os outros, enquanto eles são outros." (VALÉRY, 2005, 1925-1925, Texte 28 (X, 657)), "não julga a vida. Não é objeto da vida." (VALÉRY, 2005, 19211922, Texte 11 (VIII, 471)) Tampouco, em momento algum, refere-se a uma inquebrantável lógica de recompensas e de punições, a qualquer tipo de salvação ou perdição que, supostamente, a alma estaria sujeita, como frequentemente ocorre nos grandes sistemas religiosos do Ocidente. Não há a fácil evocação de uma doutrina que julgue o ser humano, pondo, minuciosamente, numa balança os vícios e as virtudes, as intenções e as ações que possa ter cometido ou deixado de cometer em vida, para então marcar a sua pertença na eternidade. O poeta purga seu diálogo desse tipo de "polêmica" religiosa e de qualquer tentativa de promulgar uma soteriologia, uma moral. Escrito, como diz a sua epígrafe, "Para agradar"

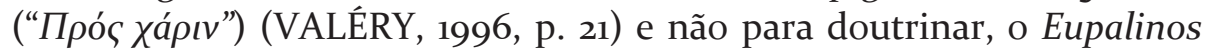
não deixa de ser uma poderosa representação de um pensamento sobre a vida e para a vida: esta é o que verdadeiramente importa; esta é o que parece ser, sub-repticiamente, a meta capital de todo esse diálogo.

1 O próprio Valéry historia como veio a escrever esse diálogo: "Eu recebi a comissão de escrever um texto para o álbum Architectures que é uma coleção de gravuras e de plantas. Esse texto, que deveria ser magnificamente impresso in-folio e exatamente ajustado à decoração e à paginação da obra, pediram-me para lhe dar um tamanho exato de 115.800 palavras... [...]/ Eu aceitei. Meu diálogo então foi muito longo. Eu o diminuí; e depois [...] eu o aumentei. Acabai por considerar essas exigências muito interessantes." (VALÉRY, 1997, p. 1401) 
A princípio, o fiel discípulo busca o seu querido mestre que, como habitualmente fazia em vida, havia se isolado, agora não dos outros vivos, mas dos outros mortos, nas "fronteiras deste império transparente" (VALÉRY, 1996, p. 21), para perder-se em si mesmo e de si mesmo. Questionado por Fedro sobre o que está pensando, Sócrates dá o insólito tom de todo o diálogo: "Não posso responder. Bem sabes que nos mortos a reflexão é indivisível. Estamos agora muito simplificados para que uma ideia não nos absorva até o final de seu curso. Os viventes têm um corpo que lhes permite sair do conhecimento e nele reentrar." (VALÉRY, 1996, p. 21) Doravante, como bons filósofos gregos que se comprazem em tudo discutir, eles procuram racionalmente avaliar a nova e estranha condição na qual se encontram. O mundo percebido pelos sentidos, o "mundo dos vivos", por mais caótico que possa às vezes parecer ou ser assim considerado, não deixa de ter uma ordenada heterogeneidade de "cores" e "formas"; há uma lógica, talvez não imediatamente nele, mas que dele pode ser depreendido. Essa propriedade e a contínua aparição e desaparição de fenômenos, que a razão avalia como semelhantes ou diferentes, permitem o prodigioso desenvolvimento mesmo da linguagem e da ciência, já que estas se assentam em regularidades. Dirse-ia que esse mundo não é um caos, uma desordem, mas um cosmos, uma ordem. O ser humano, qualquer um, pode nele -e ao fazer parte dele- distinguir um objeto do outro, pode nomeá-lo e passar esse nome às gerações futuras, na relativa esperança que os objetos continuem mais ou menos como são.

Em sua dinâmica, o "mundo dos mortos" descrito e induzido por Valéry contrasta, enormemente, com um assim posto "mundo dos vivos"; a princípio, não se distancia em muito do que, segundo o próprio Sócrates de Platão, deve ser "a realidade que é, verdadeiramente, sem cor, sem forma, impalpável, e que só pode ser contemplada pela razão, piloto da alma" (PLATO, Phaedrus, 2005, p. 474-475). Contudo, diferentemente do que essa razão possa habitualmente conjeturar, é um lugar estéril, sem referências, fluido em demasia. Os mortos são assim incapazes de precisar os contrastes e os limites, de distinguir onde ou quando uma coisa termina e outra começa: consequentemente, descrevê-las, nomeálas torna-se quase impossível. Capturados por essa celerada realidade, Sócrates e Fedro estão como que impedidos de retirar do que percebem representações fixas e, portanto, generalizações das quais se possa novamente especular. Inventar uma nova linguagem e uma nova ciência, uma nova filosofia, fazer teorias a partir desse mundo, tais tarefas seriam como que impossíveis e ingratas, já que a linguagem e a ciência, e mesmo 
a filosofia, são, ao menos em seus movimentos iniciais, derivadas da incessante relação com os fenômenos sensíveis, materiais, derivadas da experiência. Porque nesse imortal mundo, onde as almas aportam, tudo é pura passagem: tempo sem matéria; tempo -paradoxalmente- sem espaço.

FEDRO: Começo a enxergar algo. Mas nada distingo. Meus olhos, por instantes, seguem tudo o que passa e o que deriva, mas perdem-se, antes de ter discernido.../ [...]/ Creio, a cada momento, que vou discernir alguma forma, mas o que acreditei ver não desperta em meu espírito a menor similitude.

Sócrates: É que assistes [...] ao verdadeiro fluir dos seres. Desta margem tão pura, vemos todas as coisas humanas e as formas naturais movidas segundo a velocidade própria de sua essência. Somos como o sonhador, em cujo seio, figuras e pensamentos bizarramente alterados pela própria fuga, os seres se compõem com suas mudanças. Aqui tudo é indiferente e, no entanto, tudo importa. Os crimes engendram imensos benefícios e as maiores virtudes desencadeiam consequências funestas: o julgamento não se fixa em parte alguma, a ideia faz-se sensação sob o olhar, e cada homem arrasta consigo uma sucessão de monstros inextrincavelmente surgidos de seus atos e das formas sucessivas de seu corpo. Penso na presença e nos hábitos dos mortais nesse curso tão fluido, e que estive entre eles, tratando de ver todas as coisas como as vejo precisamente agora. Eu colocava a Sabedoria na postura eterna em que estamos. Mas daqui tudo é irreconhecível. A verdade está diante de nós, e não compreendemos mais nada. (VALÉRY, 1996, p. 23-25)

A verdade, não a definida pela correta relação entre representação e representado, masaontológica, enquantodescobrimentooudesvelamento daquilo que está oculto, enquanto passagem do sensível para o inteligível, enquanto abertura para o real, o homem que é capaz de reconhecêla, torna-se incapaz de compreendê-la; a verdade, miseravelmente, pouco ou de nada lhes serve. Eis, assim, que se configura a elegante e capital ironia de Valéry e a partir da qual o seu diálogo de mortos se desenvolve: as almas errantes de Fedro e de Sócrates não encontram para grande espanto de ambos os filósofos- algo que poderiam dizer, com convicção, serem as Ideias: nenhuma forma, modelo ou arquétipo, nenhum "ente eterno", nenhuma hierarquia celeste e nenhum Demiurgo os aguardavam, a eles que buscaram, em vida, caminhar na retidão da justiça e da virtude; tampouco ocorre nenhum julgamento das almas, como já no Fedro se anuncia. Nada daquilo que foi "prometido", por uma doutrina que eles mesmos (ou Platão) desenvolveram (ou reinventaram a partir da experiência com a tradição religiosa grega), no exercício especulativo de seus diálogos terrenos, ali se encontra. Nesse estranho e conjetural "mundo dos mortos", a essência é movente, e não estática: 
excessivamente movente, a ponto de a tudo liquidar ou transformar: o que em vida se considerava bom, em morte pode ser considerado mal; os opostos se misturam ou se invertem.

Aqui, evidencia-se que o diálogo Eupalinos, propositadamente ou não, dialoga com os diálogos platônicos, mais precisamente, com o próprio Fedro. (Cf. PLATO, Phaedrus, 2005) Neste, às margens do rio Ilisso, em meio a uma caminhada, procurando responder a quem se deve agradar, discutindo sobre a retórica, a beleza e o amor, Sócrates conta a um jovem Fedro justamente o "mito" da alma como carro alado e uma das versões da Teoria das Ideias; naquele, no "mundo dos mortos", é Fedro que agora conta a Sócrates suas justificadas desconfianças para com as reais vantagens que uma alma totalmente liberta do corpo venha a ter e, consequentemente, seus sentimentos para com a própria noção daquilo que venha a ser, realmente, o polivalente conceito de Ideia, particularmente, o da Ideia do Belo. Como um ousado aprendiz que honra seu mestre ao contradizê-lo, ele a questiona e a transforma: passa a não (mais) acreditar Nela como realidade em si. Onde o Belo se encontra se não há objetos sensíveis dos quais se possa dizer que são ou não belos? A beleza é sempre inexoravelmente transitória, pois deriva das coisas consideradas belas. Ela só poderia ocorrer na vida, não na morte; na matéria, não no espírito; no que passa, não no que fica: em tudo o que é "irreal". O seu conceito, como qualquer outro que não tenha como ser mesurado ou quantificado, como qualquer outro qualificativo, condiciona-se às subjetividades e às culturas, aos interesses (conscientes ou não) daqueles que o professam, ao modo como determinados padrões formais são valorizados e desvalorizados. Porque todo conceito deriva de uma experiência sensível, de um choque entre um eu e um não-eu. E a beleza -que tantas discussões suscita- a isso não foge.

FEDRo: [...] O que há de mais belo não figura no eterno!/ [...] Nada de belo é separável da vida, e vida é o que morre.

Sócrates: [...] Mas a maior parte dos homens tem da beleza uma noção imortal...

FEDRO: Eu te direi, Sócrates, que a beleza, segundo o Fedro que eu fui...

SócrATES: Platão não está nessas paragens?

FEDRO: Falo contra ele./ [...]/ [a beleza] ...não reside [...] nesses modelos situados fora da natureza, e contemplados pelas almas mais nobres como exemplares de seus desenhos e os tipos secretos de seus trabalhos; coisas sagradas, e das quais conviria falar com as próprias palavras do poeta:

Glória do longo desejo, Idéias! [Gloire du long désir, Idées!]

Sócrates: Qual poeta? 
FEDRO: O admirabilíssimo Stephanos², que apareceu tantos séculos depois de nós. Mas em meu sentimento, a ideia dessas Ideias das quais nosso maravilhoso Platão é o pai, é excessivamente simples, e também pura demais, para explicar a diversidade das Belezas, a mudança das preferências dos homens, o esquecimento de tantas obras que haviam sido elevadas às nuvens, as criações novas, e as ressurreições impossíveis de prever. Há muitas outras objeções! (VALÉRY, 1996, p. 41-43)

A partir dessa proposta de discurso, após o espanto, Sócrates e Fedro refletem e divagam sobre algo mais específico, em que o conceito mesmo de beleza costuma ser atrelado, sobre a arte e os procedimentos artísticos, sobre a ação, o fazer artístico de um distanciado amigo de Fedro, o enigmático arquiteto Eupalinos de Mégara³, a quem Sócrates desconhecia e para quem, ao fim, acaba rendendo homenagens. Na eternidade na qual se encontram, restam a eles a rememoração e a conversa; resta a eles, talvez, esta atividade que, reduzida à sua máxima simplicidade, só necessita de consciência e de memória, das experiências que não podem mais se repetir: a filosofia, que agora adquire um caráter de consolação. Visionários de um passado a ser revistado continuamente, eles acabam trocando pensamentos, quase melancólicos, como anjos que se debruçam sobre a preocupada cabeça dos mortais: suas vozes não versam mais sobre o Céu e o incondicionado, mas sobre a Terra e o condicionado. No "mundo dos mortos", os mortos se voltam para o "mundo dos vivos".

Assim, da colocação do Fedro valéryano -mais malicioso do que o singelo que se apresenta na versão platônica- de querer falar contra Platão inicia-se uma engenhosa crítica à antiga metafísica idealista. Essa crítica pode ser enunciada, em síntese, pelo seguinte paralelo: se os diálogos platônico-socráticos têm, na pluralidade dos seus interesses e contradições, como uma das metas centrais a descrição, o elogio e a promulgação do Mundo das Ideias, daquilo que é imperecível,

2 Valéry refere-se a Stéphane Mallarmé; deste, o verso citado encontra-se no poema Prose (pour des Esseintes). (Cf. MALLARMÉ, 1998, p. 28-30)

3 "O nome de Eupalinos, eu o adquiri," revela Valéry, "quando procurava o nome de um arquiteto, na Encyclopédie Berthelot no artigo "Arquitetura”. Aprendi depois, por um trabalho do sábio helenista Bidez (de Grand), que Eupalinos, mais engenheiro do que arquiteto, cavou canais e construiu poucos templos; eu o emprestei minhas ideias, como o fiz com Sócrates e Fedro. Ademais, eu nunca estive na Grécia e, quanto ao grego, eu sou infelizmente limitado, um escolar dos mais medíocres, que se apega ao original de Platão e o encontra, nas traduções, terrivelmente longo e por vezes aborrecido." (VALÉRY, 1993, p. 1402) 
imutável, os diálogos socráticos ${ }^{4}$ de Valéry -do qual o Eupalinos pode ser compreendido como a sua versão mais acabada e completa, aquele que cumpre essa concepção com mais vigor- referem-se, quase vinte quatro séculos depois, após a secularização de grande parte da civilização e o advento da Ciência Moderna, ao Mundo dos Fenômenos, daquilo que é perecível, mutável; se os primeiros se atêm à dimensão inteligível, espiritual, então os últimos se atêm à dimensão sensível, material. Uma inversão do platonismo: talvez seja justamente isso o que no Eupalinos se realiza ou se busca realizar -sem cair em excessos. Inversão que é, nesse diálogo dos mortos, executada pela leve e irônica defesa da dimensão sensível, material, como necessária ao próprio desenvolvimento humano em direção à dimensão inteligível, espiritual.

2.

Durante muito tempo foi engendrada e propagada a antropomórfica crença de que este mundo -por se estar em constante movimento, por se degenerar- é essencialmente "mal", corrompido, e tudo que nele se insira, todas as criaturas, todas as invenções e artes humanas, também compartilham, em maior ou menor grau, dessa débil natureza. A filosofia de Platão, não raras filosofias judaicas e cristãs, que muito se apropriaram do próprio platonismo, ajudaram a promover, em certa medida, essa crença, a tal ponto que se tornou, em maior ou menor grau, uma relativa constante na mentalidade do Ocidente. E se hoje, após o advento da Ciência Moderna e do processo de laicização, já não é tão operante e já tenha sido intensamente criticada, as características morais a ela atreladas, seus duros elementos psicológicos, transcendidas de seu contexto original, como pecado, culpa e remorso, ainda o são: persistem. Atrelado a isso, quiçá o que mais sofreu com isso foi o corpo -o modo como se compreendeu, ontologicamente, o corpo. Este foi definido, por Platão, como um instrumento da alma, mas também como uma prisão a obliterar e a "degenerar" a própria alma, a impedi-la de ser o que plenamente é.

Como crítica a essa última concepção e ao que ela costuma acarretar, levanta-se parte do pensamento moderno, já um tanto incapaz de suportar tal aversão aos desejos e aos afetos frequentemente condicionados pela dimensão sensível, material, assim como Valéry, que nunca deixou de escrever, paradoxalmente, entre a volúpia das sensações e o ascetismo do 
intelecto. "pelo olhar do espiritual/", sentencia o poeta em seu derradeiro

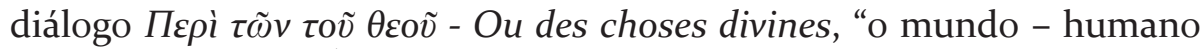
é maldito -” (VALÉRY, 2005, Folio 108) Nesse sentido, o Eupalinos é, mesmo que sub-repticiamente, mesmo que na multiplicidade de suas tão diversas reflexões, um dos seus mais incisivos escritos: não se limita apenas ao questionamento das Ideias platônicas através do estratagema literário que as "elimina" do "mundo dos mortos", mas também vai ao questionamento da tradicional desvalorização sofrida pelo corpo, desvalorização que, em parte, surge de uma apropriação ou interpretação da própria Teoria das Ideias platônicas, assim como de tantas outras metafísicas idealistas. Inverter o platonismo não é, portanto, mera crítica a Platão, pois muitas vezes a tradição que leva seu nome dele se distancia e se desvirtua; inverter o platonismo é, sobretudo, desconfiar da crença segundo a qual o importante para a vida transcende necessariamente a própria vida, segundo a qual a dimensão do fenômeno, o transitório que aos sentidos assim se apresenta, é, numa suposta hierarquia ética do cosmos, inferior à dimensão da númeno, às construções mentais que representam supostas estruturas eternas e imutáveis; inverter o platonismo é, portanto, conferir um outro valor ao corpo e ao que o corpo imediatamente se relaciona. Inserido numa sociedade que tende a aceitar com mais tolerância essa inversão, na medida em que ela já vem se operando, em maior ou menor grau, como que naturalmente desde a quase inevitável cesura entre, de um lado, a metafísica tradicional e, de outro, a Ciência Moderna e o processo de laicização, o Eupalinos de Valéry torna-se assim um verdadeiro discurso à aceitação da materialidade e a tentativa de, através de atividades como ciência, técnica e arte, transformar, mesmo que passageiramente, mesmo que de modo não durável, essa materialidade, sem a necessidade da crença no transcendente que a sustente e a justifique, que conforte e console. Por que compreender alma e corpo como duas substâncias ontologicamente opostas ou contrárias? por que, ao se almejar a felicidade eterna, acabese por adquirir uma não rara aversão ao corpo e à dimensão sensível, material, como se assim se pudesse afastar do sofrimento que advém do apego ao próprio corpo e à própria dimensão sensível, material? Não seria isso ignorar ou querer ignorar que não é necessário sofrer se, ao admirar a beleza que sente ante a ocorrência de um determinado fenômeno, aceitar que este irá nascer, crescer, envelhecer, morrer e se transformar em algo outro, que este não dura para sempre?

Valéry defende, assim, a possibilidade dessa perspectiva, a importância do corpo, sobretudo para o espírito (a inteligência) que só então plenamente se desenvolverá através dele. "O pensamento não é 
sério senão pelo corpo" (VALÉRY, 1973, p. 1120), afirma. "É a aparição do corpo que dá o seu peso, sua força, suas consequências e seus efeitos definitivos.” (VALÉRY, 1973, p. 1120) E mais: “Todo Sistema filosófico no qual o Corpo do homem não tem um papel fundamental é inepto, inapto". (VALÉRY, 1973, p. 1124)

Em favor dessa revalorização do mundo sensível, material, e, por conseguinte, do corpo, Fedro evoca, estrategicamente, caras lembranças: seus diálogos com Eupalinos, o arquiteto que lhe mostrou como executar uma arte que, diferentemente do que se possa esteticamente idealizar, é, sobretudo, um embate constante e íntimo com as possibilidades e os limites da natureza, da matéria. Para surpresa de Sócrates, os fins do arquiteto não lhe parecem ser tão diferentes dos promulgados pelos filósofos; pois não se reduzem apenas a questões de ordem pragmática, como a busca da funcionalidade de um edifício e da beleza que este cumpre suscitar, mas também a si mesmo, ao autoconhecimento socrático ou à autoconsciência valéryana. "Quanto mais medito sobre minha arte," diz o arquiteto a Fedro, "mais a exerço; quanto mais penso e faço, mais sofro e me regozijo como arquiteto; - e mais me sinto eu mesmo [...]./ [...] avanço em minha própria edificação; aproximo-me de tão exata correspondência entre meus desejos e minhas forças que tenho a impressão de haver feito da existência que me foi dada uma espécie de obra humana./ De tanto construir, disse-me sorrindo, creio ter-me construído a mim mesmo." (VALÉRY, 1996, p. 51) "Construir-se, conhecer-se a si mesmo, são dois atos ou não?" (VALÉRY, 1996, p. 51), pergunta-se Sócrates. A resposta a essa capital pergunta, para Valéry, é, naturalmente, afirmativa: conhecer-se também é construir-se... Conhecerse é agir-se, fazer-se. Contudo, para um Sócrates valéryano que, como o platônico, diz “jamais tive outro cárcere além do meu corpo" (VALÉRY, 1996, p. 57), resta a Fedro referir-se ao ideal de Eupalinos. "Imagina pois, com nitidez, um mortal bastante puro [...], poderosamente armado por Minerva para meditar até o fundo do seu ser, logo, até o extremo da realidade," assim propõe o arquiteto,

essa estranha aliança [grifo do autor] de formas visíveis com efêmeras combinações de sons sucessivos; pensa de que origem íntima e universal se aproximaria; a que precioso ponto se alçaria; que deus encontraria em sua própria carne! E, possuindo-se enfim nesse estado de divina ambiguidade, propusesse a si próprio construir não sei quais monumentos [...]! Imagina que edifícios!... [...]/ Certa vez, estive infinitamente perto de experimentá-lo, mas somente da maneira como possuímos, durante um sonho, o objeto amado. Posso apenas falar-te das aproximações a algo tão grandioso. Ao anunciar-se, caro Fedro, difiro logo de mim mesmo [...]. [...] As forças acorrem. [...] Ei-las, 
carregadas de clareza e de erro; o verdadeiro e o falso brilham igualmente em seus olhos [...]. Esmagam-me com seus dons, assediam-me com suas asas... Fedro, eis aqui o perigo! Nada há mais difícil no mundo! Ó momento supremo e dilaceramento capital!... Essas graças superabundantes e misteriosas, longe de acolhê-las tais e quais, deduzidas unicamente do grande desejo, inocentemente formadas pela extrema espera da alma, é necessário que eu as suspenda, ó Fedro, e que elas aguardem o meu sinal. E, tendo-as obtido por uma espécie de interrupção de minha vida [...], quero ainda dividir o indivisível, moderar e interromper o nascimento das Ideias... [Grifo do autor]/ - Ó infeliz, disse-lhe eu, que queres fazer no átimo de um relâmpago?/ - Ser livre! [...] há... tudo nesse instante; e tudo com que se ocupam os filósofos passa-se entre o olhar que cai sobre um objeto e o conhecimento que daí resulta... para concluírem sempre prematuramente./ [...] Esforças-te pois em retardar as Ideias?/ - É necessário. Impeço-as de me satisfazer, difiro a pura felicidade./ [...]/ Importa-me acima de tudo obter, do que irá ser, que satisfaça, com todo o vigor de sua novidade, as exigências razoáveis daquilo que foi. (VALÉRY, 1996, p. 59-63)

Partindo de um artista ideal, de um homem universal, o Eupalinos valéryano propõe, com outras palavras e num outro contexto, o mesmo método do Leonardo valéryano. Ambos são personificações de uma compreensão formalista da criação artística; ambos não creditam um significado único e fixo às obras que executam, e se aproximam no modo como contemplam e como trabalham as coisas que lhe são dadas: procuram não concluir prematuramente, procuram suspender, ao menos provisoriamente, a tendência que a consciência tem em generalizar e em universalizar, em abstrair, para poder com isso ater-se à dimensão sensível, material e compreender melhor, como que sem conceitos, como sua arte deverá ser concebida e construída. Humilde, o arquiteto não se refere a si mesmo como alguém que alcançou a plenitude dessa singular suspensão; ele caminha em direção a ela e seu caminho é uma ascese. Pratica, através de sua arte, o autoconhecimento socrático e/ou a autoconsciência valéryana. Contudo, diferentemente dos filósofos convencionais, sua meta não é apenas um ir a si mesmo fora do mundo, mas um ir a si mesmo no mundo, não é um distanciar-se, mas um aproximar-se: é, sobretudo, uma imprescindível conciliação, ou, para usar uma palavra mais condizente com uma visão relativamente idealista do passado, uma re-conciliação, ou ainda, na sugestiva e misteriosa palavra do poeta, uma "aliança" ("alliance"). (VALÉRY, 1996, p. 67) Uma aliança, não como aquela que Deus impõe ao homem, mas entre o corpo e a alma, entre a matéria e o espírito, mas também, consequentemente, entre a ciência, a

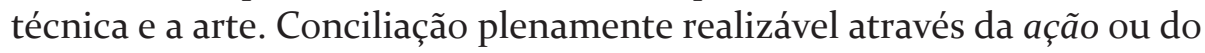
fazer, do fazer a arte, e da qual nasce a tão ansiada e procurada beleza. Assim, em sua pragmática, Eupalinos acaba professando uma sincera e 
delirante "oração sobre o corpo" e Sócrates irão especular e ultimar por si mesmos os desígnios de um pensamento que seja ao mesmo tempo prático e teórico, que resulte em obras de arte. "ao compor uma morada [...], aplicando-me em criar um objeto que delicie os olhos, que se entretenha com o espírito, que esteja de acordo com a razão e as numerosas conveniências...”, começa Eupalinos,

eu te direi esta coisa estranha que me parece entranhar-se na obra toda o meu corpo. [...] O corpo é um instrumento admirável, pelo qual me asseguro de que os viventes, tendo-o cada qual a seu serviço, dele não dispõem em plenitude; extraem apenas prazer, dor, e os atos indispensáveis para viver. Ora confundem-se com ele, ora distraem-se por algum tempo de sua existência; ora animais, ora puros espíritos, ignoram os vínculos universais que possuem. Graças, no entanto, à prodigiosa substância de que são feitos, participam do que vêem e do que apalpam; [...] trocam contatos e intimidade com a

5 Um dos ápices poéticos do Eupalinos, essa oração, que eleva o corpo, relacionase -difícil saber se Valéry assim a projetou...- com uma outra, que, em certa medida, o rebaixa. Esta se encontra no Fédon de Platão, que, mais de vinte séculos antes, relata os derradeiros momentos da vida de Sócrates, antes deste beber a cicuta; como o momento sugere, o diálogo é uma reflexão sobre o prazer e a dor, sobre as necessidades da existência sensível, material, sobre como somente os mortos podem contemplar a verdade, como somente a alma, livre do próprio corpo, é capaz de contemplá-la. A passagem aqui referida é uma fala do Sócrates platônico, a sintetizar o que até então foi discutido. Nela há algo de profético: reflete como então, pela filosofia e pela religião, o corpo irá ser "compreendido”: “"Talvez haja um curto caminho que nos leve [...] a uma conclusão," discursa Sócrates, "porque enquanto tivermos um corpo e nossa alma estiver contida nesse mal, jamais alcançaremos completamente o que desejamos, a verdade. Pois o corpo nos mantem constantemente ocupados devido a necessidade de alimentação; e, ademais, se alguma doença o ataca, nos impede a busca da verdade. O corpo enche-nos de amores, de desejos e de medos, e de toda sorte de fantasias e loucuras, de tal maneira que, para nós, como se diz, acaba se tornando impossível pensar. O corpo e seus desejos são a única causa das facções, das guerras e das batalhas [...]. Nós somos escravos de seus cuidados. E, por isso, não temos lazer para nos dedicar à filosofia. Mas o pior de tudo é que, se acaso temos algum lazer para nos dedicar à filosofia, o corpo constantemente nos interrompe, os nossos estudos, e perturba-nos com barulho e confusão, de maneira que não podemos contemplar a verdade. Percebemos então que, se quisermos saber algo de absoluto, temos de nos desvencilhar do corpo e contemplar, somente com a alma, as realidades em si mesmas. E então [...] provavelmente quando estivermos mortos é que venhamos a possuir a sabedoria que desejamos [...]. [...] E enquanto vivemos, penso, mais perto estaremos do conhecimento, se evitarmos, na medida do possível, o intercurso e a comunhão com o corpo, o contaminarmos com a sua natureza, exceto aquilo que seja absolutamente necessário, mantendo-nos puro dele até que Deus nos livre dele. Dessa maneira, libertados da loucura do corpo e sendo puros, estaremos, penso, entre os puros e conheceremos por nós mesmos tudo o que é puro -e isto talvez seja a verdade. Pois o que não é puro não pode atingir o puro."' (PLATO, Phaedo, 2005, p. 229-231) 
matéria que os engloba; [...]./ Mas sua alma não sabe se servir exatamente dessa natureza que lhe está tão próxima, e que ela penetra. Adianta-se, atrasa-se; parece fugir do próprio instante. Abalada ou impelida, retira-se para dentro dela mesma, onde se perde em seu vazio, gerando fumaça. Mas eu, inteiramente ao contrário, instruído pelos meus erros, digo em plena luz, repito a cada aurora:/ "Ó corpo meu, que me lembrais [...] o temperamento de minha índole, o equilíbrio de vossos órgãos, as justas proporções de vossas partes, que voz fazem existir e vos restabelecem no seio das coisas moventes, vigiai minha obra; ensinai-me silenciosamente as exigências da natureza; comunicai-me essa grande arte da qual sois feito, da qual sois dotado, de sobreviver às estações e de vos refazer dos acasos. Que eu encontre em vossa aliança [grifo do autor] o sentimento das coisas verdadeiras; moderai, fortalecei, assegurai meus pensamentos. Perecível que sois, vós os sois bem menos que meus sonhos; perdurais mais que uma fantasia; [...]: Instrumento vivo da vida, sois para cada um de nós o único objeto que se compara ao universo. [...] Sois verdadeiramente a medida do mundo, do qual minha alma apresenta-me apenas o exterior. Ela [a alma] o concebe sem profundidade, e tão futilmente, que por vezes se engana, contando-o entre seus sonhos; [...]... Enfatuada de suas efêmeras fabricações, [a alma] crê-se capaz de uma infinidade de realidades diferentes; imagina existirem outros mundos; mas vós [o corpo] a chamais de novo a vós mesmos, como a âncora, a si, o navio.../ [...] Mas possa a obra que agora quero fazer [...] obrigar-nos a nos responder e surgir unicamente de nosso entendimento! [...] cumpre agora que [corpo e alma] se unam em uma construção bem ordenada. [...]"

Sócrates: Que oração sem igual!... [...]/ Todas essas palavras soam estranhas neste lugar. Despojados agora de nossos corpos, devemos seguramente nos lastimar e [...] consideremos a vida que deixamos... Obras e desejos aqui não nos acompanham, mas há lugar para os arrependimentos. (VALÉRY, 1996, p. 65-71)

Livre de seu invólucro físico e de seus condicionamentos, livre das possibilidades da doença e da velhice, livre tanto da dor quanto do prazer, livre da morte e do corpo que morre, livre de tudo aquilo que a limita, uma alma não teria, numa perspectiva puramente prática, porque transformar o que é natural em artificial. Técnicas para melhor viver, trabalhar e habitar, para "progredir": tais invenções seriam totalmente estranhas. No "mundo dos mortos" de Valéry, nem a medicina nem a arquitetura seriam necessárias. Qual a utilidade de duas atividades que respondem aos anseios e às necessidades de seres encarnados para a alma que não adoece, envelhece e morre, que não necessita de alimentos e de higiene, que não necessita se proteger das intempéries da natureza, portanto, de tudo aquilo que um corpo necessita para viver no "mundo dos vivos"? Ela, a alma, poderia muito facilmente existir em eterna quietude e imobilidade, sem ter nenhum outro contato com outras almas: não haveria mais o que une ou desune os seres humanos; não haveria mais a dependência material que, direta ou indiretamente, 
“condena” a todos, aqui, ao convívio e à política, à relação com o outro e com as necessidades e desejos do outro, a uma incessante busca de equilíbrio entre as aspirações individuais e as limitações coletivas, entre os desejos e poderes de um e os desejos e poderes do outro.

Essa visão, a princípio, poderia ser considerada, como relativamente foi, positiva. Contudo, no Eupalinos, assim como em grande parte da obra de Valéry, consequências não tão favoráveis são expostas. Num tal "mundo dos mortos", separados, alma e corpo não agem, não fazem, não realizam nada de concreto: um torna-se potência inconsciente; o outro, impotência consciente. Somente quando unidos e inseridos num mundo material é que ambos são capazes de realmente agir, de fazer. Por conseguinte, também a arte não existiria, pois, mesmo não sendo uma manifestação direta da busca em suprimir as necessidades físicas, ela é uma particular transformação das formas da materialidade, logo, é feita pelo corpo e tendo em vista a realidade específica que este, pelos sentidos, recebe e/ou constrói: "A cada homem que nasce, como há um corpo, há um mundo e um tempo etc.” (VALÉRY, 2005, 1921-1922, Texte 2 (VII, 312-314)) E se qualquer ação, qualquer fazer concreto fica assim interdito a uma alma sem corpo, fica também interdito o principal veículo para o autoconhecimento ou a autoconsciência, posto que realizar, agir e fazer não têm apenas como fim a transformação da realidade exterior, mas também a realidade interior, o si mesmo. O corpo possibilita; é um dos princípios da própria possibilidade: revela-se, portanto, não como uma mera limitação, não apenas como a mera prisão-instrumento que a alma possui para acessar a moldável materialidade exterior da qual a arte se constitui, mas também como o modo mesmo da própria alma acessar o interior, a si mesmo e nesse acessar, transformar-se. $\mathrm{O}$ mais pleno autoconhecimento ou autoconsciência se dá através da matéria. A aliança entre essas duas categorias, tão recorrentemente postas em dramática oposição e conflitos por parte da tradição Ocidental, entre o corpo e a alma, tem aí a sua justificativa, não simplesmente "ética", mas, sobretudo, "estética". E a arte vem a ser, tanto em sua ação, em seu fazer, como em seus resultados, um dos principais meios materiais dessa aliança; a arte torna-se o método capital de autoconhecimento ou autoconsciência -a ascese que não nega o mundo sensível. Eis o sentido do aprendizado do incorpóreo Sócrates valéryano.

3.

Como tantas outras figuras que se instauram entre a lenda e a história, Sócrates recebeu inúmeras máscaras. Aristófanes o ridicularizou como 
um ingênuo e patético sofista; Xenofonte o desenhou como um modelo de serenidade e simplicidade; o oráculo de Delfos o proclamou como o homem mais sábio de seu tempo; Platão o considerava como o homem mais justo que conhecera. Sob o nebuloso pretexto de corromper os jovens e de instaurar novos deuses, o grande questionador foi condenado à morte, destino que aceitou de um modo extremamente resoluto, pacífico, como se não houvesse muita diferença entre este e o outro mundo. Posteriormente, outros, talvez imbuídos de um forte sentimento profético, nele viram a exemplificação avant-la-lettre da humildade ascética frequentemente recomendada ou exigida pelo Cristianismo Medieval. Tal interpretação possui fortes justificativas. Com a "ironia" de um "saber que ignora”, Sócrates não apenas tinha por hábito desobrigarse de professar a verdade, doravante parecia, por vezes, conhecê-la em segredo, mas, pondo no centro da vida a questão ética, encarava a própria filosofia como um modo de vida, como um exercício, um veículo a algo mais essencial, quiçá inefável às palavras, ao discurso. Daí também as características da rígida conduta de Sócrates, que tanto influenciaram as posteriores escolas filosóficas que na Hélade se instauraram: sua simplicidade e pobreza; seu despojamento e desapego; uma fidelidade inquebrantável a si mesmo, ao seu próprio aprendizado. Assim, dentre todas as imagens que se pode fazer desse filósofo paradigmático, desse filósofo-conceito, uma das mais constantes na tradição, é aquela que justifica e amplia essas características: a de um homem extremamente voltado para o espírito que se entretém com o conceito e a abstração.

É justamente dessa intensa e constante imagem que Valéry principia: mantém a concepção de um Sócrates aprendiz -concepção, quiçá, aquela que mais carisma "emana"- e a transforma para que atenda a suas próprias intenções. Se Leonardo da Vince é aquele que nada espera e tudo faz; se Edmond Teste é aquele que nada espera, nada faz e para quem tudo é permitido; se essas duas estranhas figuras representam, na obra de Valéry, tipos-ideais de consciências extremas, que vivem de um modo quase inumano, então Sócrates, agora transformado em uma outra personagem conceitual, mesmo em morte, mesmo para além de qualquer sociedade possível, aparece como a representação de um humano que descobre a sua própria humanidade. Ele não é, no Eupalinos, retratado -como não o foi por seus contemporâneos- como um sábio "onisciente", dono de todas as respostas, como uma pessoa acabada, definitiva, mas como um homem provisório, nobre justamente por não temer o por vezes angustioso movimento da dúvida, do desconfiar, do reconsiderar, do desconstruir, do retornar; jamais se esquecendo da rara e difícil 
arte de desistir, sabe que suas crenças não são blocos monolíticos, mas estão como que em constante transformação, moldando-se conforme as circunstâncias e os adventos. Assim, a princípio, quando recém adentrou o estranho "mundo dos mortos", o Sócrates valéryano não poderia deixar de ser relativamente fiel à sua imagem canônica e, portanto, de ter os mesmos princípios que o imortalizaram frente às inúmeras gerações vindouras. Como seu antigo mestre Parmênides, coerente com o registro da Antiguidade Clássica que frequentemente postulava a ciência do Ser como a ciência suprema, hierarquicamente superior a todas as demais, acredita que o conceito de "verdade" deve referir-se exclusivamente a uma universalidade e não a uma particularidade, que cumpre ao espírito retirar-se da massa de fenômenos sensíveis, materiais e repousar no inteligível, no espiritual. Doravante, no digressivo transcurso do diálogo, suas concepções vão, pouco a pouco, modificando-se, lapidando-se, evoluindo: auxilia-o, naturalmente, sua condição de desencarnado e a abstrata realidade na qual se encontra. Conforme Fedro lhe incita e lhe aponta, como outrora ele mesmo o fazia em vida, outros caminhos para a realização daquilo que sempre e tão-somente buscou realizar, o que há de mais excelso no homem, a divindade interna e sempre presente, Sócrates pondera, reconsidera e vai se descobrindo outro. As seguintes palavras corroboram e reiteram, mais uma vez, um dos pontos mais incisivos e constantes da crítica que Valéry tece à filosofia e ao filósofo:

Fedro: Uma só coisa, Sócrates, uma só te faltou. Homem divino, talvez não sentias necessidade alguma das belezas materiais do mundo, pois mal as apreciavas. Sei que não desdenhas a doçura dos campos, o esplendor da cidade, os mananciais de água cristalina, a sombra delicada do plátano; mas tudo isso não era para ti senão distantes ornamentos de tuas meditações [...]. $\mathrm{O}$ que havia de mais belo para bem longe de si te conduzindo, vias sempre outra coisa.

Sócrates: O homem, e o espírito do homem.

FEDRO: Mas então não encontraste, entre os homens, alguns cuja singular paixão pelas formas e pelas aparências te surpreendesse?/ [...]/ E, dos quais, inteligência e virtude nada deixavam a desejar?/ [...]/ Tu os situavas acima ou abaixo dos filósofos?

Sócrates: Depende.

FEDro: O alvo dessas criaturas te parecia mais digno ou menos digno de procura e de amor que o teu próprio?

Sócrates: Não se trata de seu alvo. Não posso pensar que existam vários BemSupremos. Mas é-me obscuro, difícil entender, que homens tão puros quanto à inteligência tenham tido necessidades de formas sensíveis e de graças corpóreas para atingir seu estado mais elevado. (VALÉRY, 1996, p. 47-51) 
A partir de então, todo o diálogo não deixa de ser um contínuo aprendizado de Sócrates. Este, ao fim, compreende o significado da aliança entre corpo e alma, que não é necessário sacrificar o sensível, o material em favor do inteligível, do espiritual, que essas duas esferas podem coexistir em harmonia, pois de fato talvez estejam, ontologicamente, numa mesma dimensão; compreende que pode haver prazer, sem aversão ou conflito, ante os elementos naturais ou artificiais, forjados ou não pela industriosa mão humana; compreende que a arquitetura, a escultura, a pintura, a dança, a música, a poesia, todas estas e outras tantas formas de se contemplar as "belezas materiais do mundo", através do ato de concebê-las e fazê-las, são práticas que, não distintas do pensamento filosófico, do puro trabalhar com conceitos, também transformam o espírito, também elevam, também purificam, pois também exigem o imperioso e difícil exercício das principais faculdades prezadas por Valéry, a razão, a atenção e o esforço. Mas essa compreensão não deixa de ser acompanhada por arrependimento. A um morto resta pouca coisa, resta apenas o voltar-se para a pura especulação, para o que fez e deixou de fazer em vida. Sócrates então reconsidera. Conjetura aquilo que o poeta insistentemente expressa ser necessário a qualquer prática: que deveria ter sido, em vida, tanto um filósofo como um artista. Ele, que sempre procurou a si mesmo, acaba, ao fim, por descobrir, mediante a concepção de arte de Eupalinos, que um dos mais efetivos caminhos para realizar essa procura é o da ação, do fazer.

FEDRO: Que queres pintar sobre o nada?

Sócrates: O Anti-Sócrates.

FEDRO: Imagino-o mais de um. [...]

Sócrates: Pois este será o... construtor. /[...]/ Não foi proveitoso, temo-o, buscar durante toda a minha vida esse Deus que tentei descobrir, perseguindo-o unicamente através de pensamentos; procurando-o com o variado sentimento do justo e do injusto, [...]. Esse Deus assim encontrado é apenas palavra nascida de palavra, e retorna à palavra. Pois a resposta que forjamos para nós mesmos seguramente não deixa nunca de ser a própria questão; e toda questão do espírito ao próprio espírito não é, e não pode ser, senão ingenuidade. Mas, ao contrário, nos atos, e na combinação dos atos, é que devemos encontrar o sentimento mais imediato da presença do divino, e o melhor emprego dessa parte de nossas forças, inútil à vida, e que parece reservada à busca de um objeto indefinível que nos ultrapassa infinitamente./ Pois, se o universo é o efeito de algum ato; esse ato, de um Ser; e de uma necessidade, de um pensamento, de uma ciência e de um poder pertencentes a esse Ser, somente com atos poderás integrar-se no grande designo e propor a ti mesmo a imitação do que fez todas as coisas. Esta é a maneira mais natural de te introduzir no lugar do próprio Deus. (VALÉRY, 1996, p. 167-169) 
No Eupalinos, o Sócrates valéryano parece arrepender-se; parece então sentir um sentimento de nostalgia, nostalgia do tempo em que vivia e caminhava, nas praças e nos mercados, em companhia das multidões e das contradições dos homens. Do mesmo modo que um exilado pode vir a conhecer e avaliar melhor a sua própria terra natal quando se encontra em uma terra estrangeira, entre idiomas e costumes distintos, ele conhece e avalia mais adequadamente os seus próprios pensamentos quando deles se distancia, quando os contempla através de uma perspectiva que não aquela na qual foram originalmente engendrados. Na pena de Valéry, o célebre filho do talhador de pedras Sofronisco tão-somente pode refletir e discursar sobre a importância do mundo sensível no mundo inteligível, onde qualquer prática técnica e artística é justamente desnecessária e impossível, onde os atos de conceber, de projetar e de construir não passam de lembranças, pois não há a matéria e as leis que a regem e a condicionam. Dir-se-ia que é pela falta, através do duro e fabuloso exercício espiritual da rememoração -uma espécie de anamnese praticada no "mundo dos mortos"-, que o célebre "pai da ironia" pode compreender a importância daquilo a que outrora era, por vezes, refratário. É a ausência determinando o valor daquilo que está ausente. Se na vida Sócrates tende a voltar-se para a morte, na morte Sócrates tende a voltar-se para a vida. Talvez ele também queira retornar. Retornar para poder, enfim encontra-se a si mesmo, encontrar-se com Deus. Todavia, não é um Deus cujo conhecimento pode ser realizado através das palavras, mas cuja realidade pode ser realizada através dos atos, da ação, do fazer: um Deus que se revela na prática criadora, artística. Ao findar seu dialogues des morts com esse metafórico discurso estéticoteológico, Valéry defende, sub-repticiamente, a concepção -frequente em toda a sua obra- segundo a qual as reflexões filosóficas permanecerão inconclusas, sujeitas à ilusão e ao erro, prisioneiras da linguagem na qual são formuladas, caso não passem pelo crivo da experiência e, sobretudo, não se desdobrem em uma vida criadora, artística.

\section{REFERÊNCIAS BIBLIOGRÁFICAS}

MALLARMÉ, Stéphane. Euvres complètes I. Paris: Gallimard, Bibliothèque de la Péiade, 1998.

. Euvres complètes II. Paris: Gallimard, Bibliothèque de la Pléiade, 2003.

PLATO. Phaedo. Trad. Harold North Fowler. Cambridge \& London: Harvard University Press, Loeb Classical Library, 2005. 
464 - Remate de Males 32.2

PLATO. Phaedo. Phaedrus. Trad. Harold North Fowler. Cambridge \& London: Harvard University Press, Loeb Classical Library, 2005.

VALÉRY, Paul. Caheirs I. Choix de textes. Org. Judith Robinson-Valéry. Paris: Gallimard, 1973.

. Caheirs II. Choix de textes. Org. Judith Robinson-Valéry. Paris: Gallimard, 1974. . Euvres I. Paris: Gallimard, 1997.

. Euvres II. Paris: Gallimard, 1993.

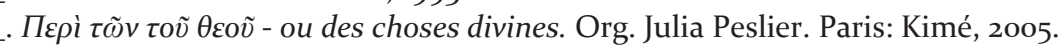
. Eupalinos - Ou o arquiteto, trad. Olga Reggiani, Editora 34, São Paulo, 1996. 